\title{
Animal models for human T-lymphotropic virus type 1 (HTLV-1) infection and transformation
}

\author{
Michael D Lairmore*,1,2,3, Lee Silverman ${ }^{1,5}$ and Lee Ratner ${ }^{4}$ \\ ${ }^{1}$ Center for Retrovirus Research and Department of Veterinary Biosciences, The Ohio State University, Columbus, OH 43210-1093, \\ USA; ${ }^{2}$ Department of Molecular Virology, Immunology and Medical Genetics, The Ohio State University, Columbus, OH 43210- \\ 1093, USA; ${ }^{3}$ Comprehensive Cancer Center, The Arthur G James Cancer Hospital and Solove Research Institute, The Ohio State \\ University, Columbus, OH 43210-1093, USA; ${ }^{4}$ Department of Medicine, Pathology, and Molecular Microbiology, Division of Biology \\ and Biological Sciences, Campus Box 8069, 660 S. Euclid Ave., Washington University School of Medicine, St Louis,
}

MO 63110-1093, USA

Over the past 25 years, animal models of human T-lymphotropic virus type 1 (HTLV-1) infection and transformation have provided critical knowledge about viral and host factors in adult T-cell leukemia/lymphoma (ATL). The virus consistently infects rabbits, some non-human primates, and to a lesser extent rats. In addition to providing fundamental concepts in viral transmission and immune responses against HTLV-1 infection, these models have provided new information about the role of viral proteins in carcinogenesis. Mice and rats, in particular immunodeficient strains, are useful models to assess immunologic parameters mediating tumor outgrowth and therapeutic invention strategies against lymphoma. Genetically altered mice including both transgenic and knockout mice offer important models to test the role of specific viral and host genes in the development of HTLV-1-associated lymphoma. Novel approaches in genetic manipulation of both HTLV-1 and animal models are available to address the complex questions that remain about viral-mediated mechanisms of cell transformation and disease. Current progress in the understanding of the molecular events of HTLV-1 infection and transformation suggests that answers to these questions are approachable using animal models of HTLV-1-associated lymphoma

Oncogene (2005) 24, 6005-6015. doi:10.1038/sj.onc.1208974

Keywords: HTLV-1; animal models; leukemia; lymphoma

\section{Introduction}

Human T-lymphtropic virus type 1 (HTLV-1), a member of the deltaretroviruses, is the causative agent of adult T-cell leukemia/lymphoma (ATL) (Yoshida et al., 1982), a highly aggressive CD4 + T-cell malignancy. Over the past 25 years, a variety of animal

\footnotetext{
*Correspondence: MD Lairmore, Center for Retrovirus Research and Department of Veterinary Biosciences, The Ohio State University, 1925 Coffey Road, Columbus, OH 43210-1093, USA;

E-mail: lairmore.1@osu.edu

${ }^{5}$ Millennium Pharmaceuticals Inc., Cambridge, MA, USA
}

models of HTLV-1, infection and transformation have provided fundamental information about viral and host determinants of this devastating malignancy (Table 1). The virus consistently infects rabbits (Akagi et al., 1985; Lairmore et al., 1992), some non-human primates (Nakamura et al., 1987; Murata et al., 1996), and to a lesser extent rats (Suga et al., 1991; Ibrahim et al., 1994). Viral transmission in mice using typical methods of infection produces inconsistent infections and limited virus expression in tissues (Fang et al., 1998; Feng et al., 2001; Furuta et al., 2002a, b; Nitta et al., 2003). Nonhuman primates have been infected with HTLV-1 and certain species have a natural infection with simian T-lymphotropic virus infection type 1 (STLV-1) (Gessain and Dethe 1996; Takemura et al., 2002; Gabet et al., 2003). The squirrel monkey has been successfully infected with HTLV-1 and offers an attractive nonhuman primate model of HTLV-1 for vaccine testing (Kazanji, 2000; Kazanji et al., 2001; Mortreux et al., 2001a; Sundaram et al., 2004). Rats have been infected with HTLV-1-producing cells and offer a tractable model of HTLV-1-associated myelopathy/tropical spastic paraparesis (HAM/ATL), the neurologic disease associated with the viral infection (Suga et al., 1991; Ishiguro et al., 1992; Kasai et al., 1999; Sun et al., 1999; Kannagi et al., 2000; Hakata et al., 2001). In addition, rats have been used to test the role of cell-mediated immunity to the infection (Kannagi et al., 2000; Hasegawa et al., 2003). However, controversy exists regarding the reproducibility of the viral infection in rats (Ibrahim et al., 1994). Bovine leukemia virus (BLV) infection of sheep offers a reliable model of disease associated with deltaretrovirus infections and insight into viral genetic determinants of tumor induction (Willems et al., 2000). This review will focus on current progress in the development of animal models of HTLV-1 infection and transformation.

HTLV-1 replication and mechanisms of carcinogenesis

Understanding HTLV-1 replication forms the basis of development for animal models of the viral-induced 
Table 1 Animal models of HTLV-1 infection and disease

\begin{tabular}{|c|c|c|}
\hline Animal $^{\mathrm{a}}$ & Advantages & Disadvantages \\
\hline Rabbit & $\begin{array}{l}\text { Low cost and ease of maintenance } \\
\text { Easy to induce persistent infection and test immune } \\
\text { response, transmission routes, and parameters of } \\
\text { infection, for example, viral loads } \\
\text { Evaluation of viral genetic determinants of infection } \\
\text { using HTLV-1 molecular clones }\end{array}$ & $\begin{array}{l}\text { No reliable disease induced following infection } \\
\text { Lack of broadly available reagents to study }\end{array}$ \\
\hline Rat & $\begin{array}{l}\text { Low cost, ease of maintenance, and can be genetically } \\
\text { modified } \\
\text { Can become persistent infected to test immune response } \\
\text { (e.g. cytotoxic T cells) and parameters of infection, for } \\
\text { example, viral loads } \\
\text { Some strains useful for neurologic disease model } \\
\text { Immunologic reagents available }\end{array}$ & $\begin{array}{l}\text { Wide variation in infection in some strains } \\
\text { Disease induced following infection does not histologically } \\
\text { model human neurologic disease } \\
\text { ATL models require immunodeficient rats }\end{array}$ \\
\hline $\begin{array}{l}\text { Immunocompetent } \\
\text { mice }\end{array}$ & $\begin{array}{l}\text { Low cost, ease of maintenance, and can be genetically } \\
\text { modified } \\
\text { Can test immune response (e.g. cytotoxic T cells) } \\
\text { Immunologic reagents available }\end{array}$ & $\begin{array}{l}\text { Limited evidence of in vivo spread of infection } \\
\text { No apparent disease induced following infection }\end{array}$ \\
\hline Non-human primate & $\begin{array}{l}\text { Phylogenetic similarity to humans } \\
\text { Good model for persistent infection } \\
\text { Development of HTLV-like disease using molecular } \\
\text { clones reported } \\
\text { Immunologic reagents available }\end{array}$ & $\begin{array}{l}\text { Cost and availability } \\
\text { Inconsistent disease development after prolonged period of } \\
\text { time }\end{array}$ \\
\hline $\begin{array}{l}\text { Immunodeficient } \\
\text { mice (e.g. NOD/ } \\
\text { SCID) }\end{array}$ & $\begin{array}{l}\text { Development of lymphoma following transplantation } \\
\text { Used to test therapeutic reagents against tumor } \\
\text { Immunologic reagents available }\end{array}$ & $\begin{array}{l}\text { Cost and complicated maintenance } \\
\text { Available of ATL cell lines to induce tumors is limited }\end{array}$ \\
\hline $\begin{array}{l}\text { Transgenic or } \\
\text { knockout mice }\end{array}$ & $\begin{array}{l}\text { Induction of lymphoma and other lymphocyte-mediated } \\
\text { diseases using individual gene products of HTLV-1 } \\
\text { Immunologic reagents available } \\
\text { Ability to test of host parameters in induction of disease, } \\
\text { for example, cytokines }\end{array}$ & $\begin{array}{l}\text { Cost of production and maintenance } \\
\text { CD } 4+\text { T-cell lymphomas inconsistently produced } \\
\text { Overexpression of viral gene products may not be } \\
\text { representative of carcinogenesis in HTLV-1 infection }\end{array}$ \\
\hline
\end{tabular}

${ }^{a}$ Excluding BLV and STLV animal models

malignancy. HTLV-1 is a complex retrovirus with type $\mathrm{C}$ retroviral morphology. The virus belongs to the deltaretrovirus group along with BLV and other primate lymphotropic viruses including STLV-1. Unlike simple retroviruses, complex retroviruses like HTLV-1 carry additional genes to encode for several regulatory and accessory proteins. As a complex retrovirus, HTLV-1 encodes regulatory proteins from the $\mathrm{pX}$ region (between env and $3^{\prime}$-LTR), by alternative splicing from four open reading frames (ORF). ORF IV and ORF III encode regulatory proteins Tax (Transcriptional Activator of $\mathrm{pX}$ region) and Rex, respectively (Kiyokawa et al., 1985; Seiki et al., 1985). Tax, a $40 \mathrm{kDa}$ nuclear protein produced from a doubly spliced mRNA, is transactivator of HTLV-1 gene transcription from the viral LTR (Felber et al., 1985; Sodroski et al., 1985). Tax forms complexes with DNA-binding proteins, such as CREB, to contact GC-rich sequences flanking the Tax-responsive element 1 (TRE-1) for the transactivation of the LTR (Kimzey and Dynan, 1999; Lenzmeier et al., 1999). Tax enhances the binding of cyclic AMP response/activator of transcription proteins to the TRE-1 and several basic leucine zipper proteins to the TRE-2 (Perini et al., 1995). In addition, Tax regulates the expression of numerous cellular genes, predominantly by induction of the transcription factors nuclear factor kappa of $\mathrm{B}$ cells $(\mathrm{NF}-\kappa \mathrm{B})$ and serum response factor, independent of CREB activation (Gatza et al., 2003; Jeang et al., 2004; Kehn et al., 2004). Rex, a nucleolar localizing $27 \mathrm{kDa}$ protein, is responsible for nuclear export of unspliced $(\mathrm{gag} / \mathrm{pol})$ and singly spliced (env) viral RNA to the cytoplasm. Even though Rex is not required for in vitro immortalization by HTLV-1, Ye et al. (2003) reported that Rex is critical for efficient infection of cells and persistence in vivo.

In addition to the regulatory proteins Tax and Rex, the HTLV-1 pX genome region encodes four accessory proteins, $\mathrm{p} 12^{\mathrm{I}}, \mathrm{p} 27^{\mathrm{I}}, \mathrm{p} 13^{\mathrm{II}}$, and $\mathrm{p} 30^{\mathrm{II}}$ from alternatively spliced forms of mRNA in ORF I and II (Berneman et al., 1992; Koralnik et al., 1992, 1993; Ciminale et al., 1995). These proteins are important for in vivo viral infectivity, host cell activation, and regulation of gene transcription (Collins et al., 1998; Ciminale et al., 1999; Trovato et al., 1999; Albrecht et al., 2000, 2002; Bartoe et al., 2000; D'Agostino et al., 2000; Zhang et al., 2000, 2001; Ding et al., 2002; Franchini et al., 2003; Kim et al., 2003; Michael et al., 2004; Nicot et al., 2004; Younis et al., 2004). The role of these accessory proteins in HTLV-1-mediated transformation has not been 
elucidated, but they are clearly important in the ability of the virus to infect and spread in vivo.

\section{Adult T-cell leukemia/lymphoma}

Animal models of HTLV-1 transformation ideally mimic the variety of forms of ATL- or HTLV-1-associated diseases. Typically, $1-5 \%$ of HTLV-1-infected individuals develop ATL after a latent period of 20-30 years (Yamaguchi and Takatsuki, 1993; Cleghorn et al., 1995). ATL is an aggressive T-cell malignancy with a leukemic phase characterized by circulating, activated CD4 +/CD25 + T cells (Uchiyama et al., 1977). Infection early in life is associated with the development of ATL and the estimated lifetime risk is about $5 \%$ in individuals infected before the age of 20 years (Cleghorn et al., 1995; Wilks et al., 1996). The incidence rate is 2-4 per 100000 person-years and males have higher risk than females (Kondo et al., 1989; Cleghorn et al., 1995). The clinical features, treatment and prevention of ATL are reviewed in this volume.

The development of ATL has been the focus of many investigations, but the exact mechanism is not completely understood. After infecting CD4 + CD25 + T cells, the HTLV-1 provirus is randomly integrated into the host genome, where it persists for years. Although HTLV-1 replicates via reverse transcription during the early stages of infection, the virus genome is effectively replicated during clonal expansion of infected cells (Mortreux et al., 2003). Typically, there is a progression from polyclonal to oligoclonal and then to monoclonal proliferation in vivo, which is achieved while the cells become interleukin 2 (IL-2) independent (Yoshida et al., 1984; Hollsberg et al., 1992; Franchini, 1995). Based on the long clinical latency and the low percentage of individuals who develop ATL, T-cell transformation is believed to be the result of a series of cellular alterations and/or mutations. Transformation of infected lymphocytes is believed to be initiated through induction of cellular genes and alterations in critical cellular activation and death pathways by the viral transactivator Tax (Gatza et al., 2003).

Intriguingly, despite a strong immune response mounted against the HTLV-1, the virus is able to persist in the host. Several possible mechanisms have been suggested to explain this observation: often the genome is partly deleted, resulting in defective virus that may provide a mechanism for escape from immune surveillance (Bangham 2000, 2003a,b). Recent reports (Asquith et al., 2000) suggest that HTLV-1 infection is in a dynamic balance between the immune response and virus replication (Asquith et al., 2000). What determines whether an HTLV-1-infected individual will progress to develop ATL is unclear. In the early course of HTLV-1 infection, integration of the provirus into host cell chromatin is random and polyclonal (Mortreux et al., 2003). During the long premalignant phase, there is oligoclonal expansion of HTLV-1-infected cells (Wattel et al., 1995; Cavrois et al., 1996; Etoh et al., 1997).
Somatic mutations are increased in peripheral blood mononuclear cell (PBMC) DNA from ATL patients compared to asymptomatic carriers (Mortreux et al., 2003). Somatic mutations are increased in both the provirus and within the proviral flanking sequences, and these mutations are thought to primarily arise during the clonal proliferative phase rather than during reverse transcription (Mortreux et al., 2001b).

Factors that impair the cellular immune response and promote $\mathrm{T}$-cell proliferation are thought to increase genetic instability of the virus and therefore increase the likelihood of development of ATL (Mortreux et al., 2003). One such factor is the HTLV-1 Tax protein. Tax expression promotes cellular proliferation and increase genetic instability (reviewed in Yoshida, 2001; Mortreux et al., 2003). In general, one of the tenets of malignant progression is that it requires mutations in several genes, including oncogenes, tumor suppressor genes, DNA repair genes, and apoptosis-regulating genes. Tax has been demonstrated to regulate gene expression of the apoptosis-regulating genes, $b c l-x L$ (Tsukahara et al., 1999) and bax (Brauweiler et al., 1997), the DNA repair genes, PCNA (Ressler et al., 1997) and $\beta$-polymerase (Jeang et al., 1990), the cell cycle regulators, cyclin D2, cyclin E, E2F1, CDK2, CDK4,CDK6, p19 (INK4d), and p27 (Kip1) (Iwanaga et al., 2001), and the tumor suppressor, p53 (de La et al., 2003). Therefore, Tax can promote malignant progression not only by increasing cellular proliferation but also by altering the expression of genes known to have the potential to contribute to malignant progression. Thus, over the past two decades, most animal models of ATL have focused on Tax and its role in lymphocyte transformation.

The route of primary HTLV-1 infection is also correlated with the course of clinical disease. Specifically, most cases of ATL occur subsequent to mucosal exposure, whereas most cases of HAM/TSP occur subsequent to intravenous exposure (Osame et al., 1990; Kannagi et al., 2000). Interestingly, oral inoculation of rats with HTLV-1 generally results in a persistent infection with immune unresponsiveness (Kato et al., 1998), whereas intravenous inoculation results in strong antibody and T-cell responses (Kannagi et al., 2000). Extrapolating from this, it is currently believed that intravenous exposure in humans also results in the strong immune response typical of HAM/TSP patients, whereas oral (mucosal) exposure allows for an initial diminished immune response and subsequent survival and outgrowth of infected CD4 $+\mathrm{T}$ cells. Intravenous exposure initially leads to infection of a large number of circulating T-lymphocytes, whereas mucosal exposure initially leads to infection of macrophage and dendritic cells and only a small number of T-lymphocytes (reviewed in Grant et al., 2002). HTLV-1 has the ability to stimulate T-lymphocytes to enter the cell cycle and promote high levels of gene expression, whereas mucosal dendritic cells and macrophages are postmitotic and therefore not likely to produce high levels of virus following infection (Grant et al., 2002). As immune response correlates with virus production, the lower levels of viral production by macrophages and dendritic 
cells may lead to an initially diminished immune response following oral exposure.

\section{Animal models of HTLV-1 infection and disease}

\section{Rabbit models}

Rabbits are used extensively as a model of HTLV-1 infection in humans because of the ease and consistency of transmission of the viral infection in this species. Infectivity for rabbits was first demonstrated in the mid1980s using intravenous inoculations of the MT-2 cell line (Akagi et al., 1985), a T-cell leukemia cell line established from a patient with ATL, and with the Ra-1 cell line (Miyoshi et al., 1985), a rabbit lymphocyte cell line derived from cocultivation of rabbit lymphocytes with MT-2 cells. Early studies in rabbits verified routes of transmission (e.g. blood, semen, milk) for the virus infection (Kotani et al., 1986; Uemura et al., 1986, 1987; Hirose et al., 1988; Iwahara et al., 1990; Kataoka et al., 1990). Pioneering studies utilizing the rabbit model of HTLV-1 have provided important clues as to the number of cells capable of transmitting the virus infection (Kataoka et al., 1990) and effective means to prevent the transmission of the virus (Takehara et al., 1989; Kataoka et al., 1990; Sawada et al., 1991; Miyoshi et al., 1992; Tanaka et al., 1994).

The rabbit model has provided important knowledge of the immune response against HTLV-1 infection. Early studies defined the sequential development of antibodies against the virus infection (Cockerell et al., 1990), and methods to detect HTLV-1 proviral DNA in infected tissues (Cockerell et al., 1990). Inoculation of rabbits with HTLV-1-infected cell lines derived from patients with ATL or HAM/TSP demonstrate the heterogeneity in the biological response to HTLV-1 infection (Lairmore et al., 1992). Immunization of rabbits with synthetic peptides verified immunodominant epitopes of the viral envelope protein (Env) (Lal et al., 1991; Tanaka et al., 1991) and also defined regions of Env important for antibody-dependent cell-mediated cytotoxicity (Chen et al., 1991). Soon after, it was demonstrated that peptide immunization with amino acids 190-199 of the Env protein could protect rabbits from subsequent HTLV-1 challenge, opening the possibility for vaccine development (Tanaka et al., 1994). More complex synthetic peptides, which use chimeric constructs that mimic native viral proteins, have also been generated and tested in rabbit models (Conrad et al., 1995; Frangione-Beebe et al., 2000).

Infectious molecular clones of HTLV-1 were first developed in the mid-1990s (Kimata et al., 1994; Derse et al., 1995; Zhao et al., 1995). These molecular clones were used to immortalize human PBMCs to create the $\mathrm{ACH}$ cell line, which was then used to infect rabbits (Collins et al., 1996). It was demonstrated that the lethally irradiated ACH cell line successfully establishes infection in the PBMCs of rabbits (Collins et al., 1996). Subsequently, ACH clones with mutations within the ORF encoding the HTLV-1 accessory proteins, $\mathrm{p} 12^{\mathrm{I}}$, p13 ${ }^{\mathrm{II}}$, and $\mathrm{p} 30^{\mathrm{II}}$, were generated (Robek et al., 1998), and inoculated into rabbits to demonstrate the necessity of these accessory proteins for establishment of infection and maintenance of proviral loads (Collins et al., 1998; Bartoe et al., 2000; Silverman et al., 2004). The necessity of the Rex protein for in vivo infection has also recently been demonstrated in the rabbit model (Ye et al., 2003).

Establishment of a rabbit model of clinical HTLV-1 disease has been more problematic. In the majority of studies, rabbit infection has paralleled the asymptomatic infection of humans. A few groups have reproduced an 'ATL-like disease' via intraperitoneal or intravenous injection of HTLV-1-transformed cells; however, this required a minimum of $1 \times 10^{8}$ cells in the inoculum, and death occurred within the first few weeks of inoculation (Seto et al., 1988; Ogawa et al., 1989; Zhao et al., 1993). These studies did not demonstrate if the leukemic cells were from the inoculum or generated de novo. Sporadic reports of clinical disease in HTLV-1-infected rabbits include uveitis (Taguchi et al., 1993), cutaneous lymphoma (Simpson et al., 1996; Kindt et al., 2000), and thymoma (Zhao et al., 2002). In each of these cases, clinical disease developed after 1 year and usually several years after the initial infection.

\section{Rat models}

Experimental infection of rats with HTLV-1 was first established in 1991 (Suga et al., 1991). Although initial experimental infection was achieved with F344 rats, it was later established that there was considerable differences in the response of various rat strains to HTLV-1 infection (Ishiguro et al., 1992; Kushida et al., 1993; Ibrahim et al., 1994). Wistar-King-AptekmanHokudai (WKAH) rats emerged as a model of HAM/ TSP. HTLV-1-infected WKAH rats develop spastic paraparesis with degenerative thoracic spinal cord and peripheral nerve lesions several months following inoculation (Ishiguro et al., 1992; Kushida et al., 1993). The pathology of rat HAM/TSP differs from that seen in humans. Lesions in humans have a marked T-cell infiltration of affected regions, whereas lymphocytes are not seen in the lesions in rats (Yoshiki, 1995). Subsequent studies defined the time periods over which the pathologic changes occur (Ohya et al., 1997, 2000), and indicated that apoptosis of oligodendrocytes and Schwann cells is the primary event leading to demyelination (Yoshiki 1995, 1997; Ohya et al., 1997, 2000). Macrophages are seen in the lesions of rats in response to the demyelination. Production of HTLV-1 pX mRNA, tumor necrosis factor (TNF) alpha mRNA, as well as altered expression of the apoptosis-modifying genes, bcl-2, bax, and p53, have been identified within the lesions (Ohya et al., 1997, 2000; Tomaru et al., 2003). In addition, HTLV-1 provirus has been identified in microglial cells and macrophages associated with lesions (Kasai et al., 1999).

Development of rat models for clinical ATL has required the use of immunodeficient rats. Ohashi et al. (1999) demonstrated that an 'ATL-like lymphoproliferative disease' could be established in adult nude $(\mathrm{nu} / \mathrm{nu})$ 
rats following inoculation of some, but not all, HTLV-1immortalized cell lines. This led to studies that examined methods of protection against tumor development, including adoptive transfer of $\mathrm{T}$ cells (Kannagi et al., 2000) and Tax-specific peptide vaccines (Hanabuchi et al., 2001). A protective effect was achieved with each of these systems. Most recently, a protective effect against tumor formation in nude rats was achieved with Tax-specific small interfering RNAs (siRNA) (Nomura et al., 2004).

\section{Non-human primate models}

Experimental HTLV-1 infection, without disease development, in non-human primates was demonstrated in several monkey species inoculated with MT-2 cells, Ra-1 cells, or autologous HTLV-1-infected cell lines (Miyoshi et al., 1984; Yamamoto et al., 1984; Nakamura et al., 1986). Recently, the squirrel monkey has been established as an experimental model of HTLV-1 infection. Peripheral lymphocytes, spleen, and lymph nodes were verified as major reservoirs for HTLV-1 virus during the early phase of infection (Kazanji et al., 1997, 2000; Kazanji, 2000). It was subsequently established that similar to humans, HTLV-1 infection in squirrel monkeys begins through reverse transcription of the virus genome, which is then followed by clonal expansion of infected cells (Mortreux et al., 2001a).

Early studies tested for antibodies specific for HTLV-1 membrane antigens in macaques with malignant lymphoma (Homma et al., 1984; Kanki et al., 1985). An experimentally HTLV-1-inoculated rhesus macaque developed arthritis, uveitis, and polymyositis (Beilke et al., 1996). More recently, development of clinical disease was reported in pig-tailed macaques following inoculation with a pig-tailed macaque cell line persistently infected with the ACH HTLV-1 molecular clone (McGinn et al., 2002). In this report, pig-tailed macaques died naturally at 35-82 weeks postinoculation with lymphopenia, arthropathy, and diarrhea. Like humans with HTLV-1 infection, macques that survived exhibited various combinations of rash, diarrhea, lymphadenopathy, and lymphopenia.

Vaccine candidates against HTLV-1 infection have been tested in non-human primates as early as 1987 (Nakamura et al., 1987). Subsequently, successful passive immunization has been achieved with hyperimmune globulin from healthy donors (Murata et al., 1996; Akari et al., 1997). Successful immunization against HTLV-1 infection has also been accomplished with recombinant vaccinia virus expressing envelope or gag gene products in combination with DNA vaccines (Ibuki et al., 1997; Kazanji et al., 2001).

\section{Mouse models of HTLV-1 infection}

Mouse models of ATL would be useful in providing a small and inexpensive animal for studies of pathogenesis, treatment, and prevention. Unfortunately, HTLV-1 does not efficiently infect murine cells, and thus, mouse models must be manipulated to establish HTLV-1 infection. HTLV-1 carrier mice can be established by intraperitoneal inoculation of $\mathrm{MT}-2$ cells into $\mathrm{C} 3 \mathrm{H} / \mathrm{HeJ}$ and BALB/c mice (Kushida et al., 1997; Fang et al., 1998; Feng et al., 1999). Intraperitoneal injection of HTLV-1-producing MT-2 cells into neonatal $\mathrm{C} 3 \mathrm{H} / \mathrm{HeJ}$ mice did not result in detectable antigen or antibody production, although provirus was detected in spleen, lymph node, and thymus at 15 weeks of age and was integrated in the mouse genome. In splenocytes, there was preferential infection of T-lymphocytes. After 18 months, HTLV-1 provirus was detected in spleen DNA in eight of nine $\mathrm{C} 3 \mathrm{H} / \mathrm{HeJ}$ mice, with polyclonal integration (Tanaka et al., 2001). Within these mice, provirus was identified within CD $4+\mathrm{T}$ cells, CD8 $+\mathrm{T}$ cells, B cells, and granulocytes within the spleen (Feng et al., 1999). Provirus was also identified within various tissues including thymus, lymph nodes, lung, liver, and kidney, although the cell type containing provirus in these organs was not identified, and the proviral loads were not quantitated (Kushida et al., 1997; Fang et al., 1998). Interestingly, neither viral mRNA production nor an HTLV-1 antibody response was found in the majority of these mice, thus this model fails to mimic persistently infection humans (Kushida et al., 1997; Fang et al., 1998). Moreover, similar to the rabbit and rat models, progression to ATL has not been demonstrated in the immunocompetent mouse.

In an attempt to improve the efficiency of infection, a chimeric HTLV-1 virus was used in which the HTLV-1 env gene was replaced by the ecotropic Moloney murine leukemia virus env gene (Delebecque et al., 2002). The chimeric virus was able to replicate in murine cells in culture, but T-cell transformation was not evaluated. Infection of $\mathrm{BALB} / \mathrm{c}, \mathrm{C} 3 \mathrm{H} / \mathrm{HeJ}, \quad 129 \mathrm{~Sv}$, and 129SvIFNAR - / - mice resulted in persistent infection with $500-800$ proviral copies $/ 10^{5}$ splenocytes in the majority of mice. In addition, virus was detected in several organs, including lymphoid organs, CNS, lung, and gonads. Importantly, this model demonstrated preferential infection of CD4 + cells and oligoclonal integration of the virus in infected cells. While these mice did not develop lesions, they did have persistent humoral and cellular immune responses.

\section{Tumor transplant models in mice}

The severe combined immunodeficiency (SCID) mouse has been a successful model to investigate the proliferative and tumorigenic potential of ATL cells (Ishihara et al., 1992; Feuer et al., 1993; Kondo et al., 1993; Ohsugi et al., 1994). SCID mice inoculated with ATL cells succumb to lymphomas, and tumor cells recovered from mice retain the phenotypic and genotypic characteristics of the original tumor cell inoculate (Feuer et al., 1993; Kondo et al., 1993; Imada et al., 1995). Interestingly, HTLV-1-infected cell lines of nonleukemic origin are not tumorigenic following SCID mouse engraftment (Feuer et al., 1995; Imada et al., 1995; Uchiyama, 1996). Inoculation of HTLV-1-infected 
nonleukemic cell lines will form tumors in SCID mice only when natural killer (NK) cell activity has been suppressed by sublethal irradiation or by treatment of animals with antiserum, which transiently abrogates NK activity (anti-asialo-GM1) (Feuer et al., 1995). Murine NK cells directly mediate cytolysis of cells harboring active HTLV-1 gene expression, suggesting that the absence of viral gene expression in ATL cells contributes to the ability of these cells to evade immune surveillance in humans (Stewart et al., 1996). The absence of viral gene expression in the HTLV-1 leukemias of SCID mice has been confirmed (Imada et al., 1995, 1996). The inability of HTLV-1-infected nonleukemic cell lines to induce tumorigenesis has also been recently demonstrated in SCID/bg and nonobese diabetic/SCID (NOD/ SCID) mice (Liu et al., 2002). Using an SCID/bg mouse model, Richard et al. (2001) were able to develop a model for ATL with associated humoral hypercalcemia of malignancy. Interestingly, elevation of parathyroid hormone-related protein in this model was shown to be independent of Tax expression. SCID models of ATL have proven useful in examining treatment strategies for ATL. Variable success in tumor suppression has been achieved with the proteasome inhibitor, PS-341 (Tan and Waldmann, 2002), humanized anti-CD2 monoclonal antibody (Zhang et al., 2003b), an NF- $\kappa \mathrm{B}$ inhibitor (Dewan et al., 2003), and humanized anti-CD52 monoclonal antibody (Zhang et al., 2003a). Recently, SCID mice less than 5 weeks old with low NK cell activity developed rapid tumor formation resulting in death (Ohsugi et al., 2004). In summary, transplantation models demonstrate unique properties of ATL cells compared to T-lymphocytes immortalized by HTLV-1 in culture, which correlate with limited viral gene expression and resistance to NK cell-mediated cytotoxicity.

\section{Transgenic models}

Transgenic mouse models of HTLV-1 have provided an understanding of the role of Tax and Tax-mediated disruption of lymphocyte function or cytokines in HTLV-1-associated lesions. Nerenberg (1990) described neurofibromas in HTLV-1 promoter (LTR)-Tax transgenic mice and used antisense inhibition of NF- $\kappa \mathrm{B}$ to demonstrate its role in tumor growth. Lymphocytemediated arthropathy developed in Tax transgenic mice controlled through the HTLV-1 promoter (Iwakura et al., 1991, 1995; Yamamoto et al., 1993; Fujisawa et al., 1996). Increased levels of nerve growth factor, granulocyte-macrophage colony-stimulating factor (GM-CSF) and IL-2 receptor also developed in transgenic mice in which Tax was expressed from the human granzyme B promoter (GzmB) (Grossman and Ratner, 1997). Transgenic mice expressing Tax under the regulatory control of the CD3-epsilon promoter-enhancer manifested salivary and mammary adenomas (Hall et al., 1998). Overall, these studies provide strong support for the oncogenic capabilities of Tax, although they did not demonstrate mechanisms of carcinogenesis.
To improve Tax expression in lymphoid compartments, various investigators have utilized alternative promoters in transgenic mice. HTLV-LTR-c-myc and immunoglobulin enhancer/promoter (Ig-enh)-Tax transgenic mice lines have been crossed resulting in the development of a variety of tumors (Benvenisty et al., 1992). Transgenic mice that specifically target the mature T-cell compartment by using the GzmB promoter develop large granular lymphocytic (LGL) tumor development (Grossman et al., 1995). Tumors composed of large granular lymphocytes developed in these mice on the tail, legs, and ears. Another interesting feature of the GzmB-Tax transgenic mice is the presence of osteolytic bone lesions, similar to those found in ATL patients (K Weilbaecher, Washington University, manuscript submitted). This represents a unique animal model with a high frequency of metastatic bone lesions, thus providing opportunities to study pathogenesis and treatment of this common complication of metastatic tumors in humans. Lines of LGL cells cultured from these mice displayed surface markers indicating a preNK cell lineage (positive for Fc $\gamma$ RII/III, IL-2 $\beta$, CD44, Thy 1.2, 5E6) (Grossman and Ratner, 1997). Tumors arising in these mice exhibited high levels of NF- $\kappa \mathrm{B}$ expression, and expression of $\mathrm{NF}-\kappa \mathrm{B}$ target genes, including $I L-6, I L-10$, and $I L-15, G M-C S F$, and interferon-gamma (IFN- $\gamma$ ) (Grossman and Ratner, 1997; Portis et al., 2001b). Primary tumor cells from these mice expressed IL-1, IL-6, IL-10, and IL-15, GMCSF, and IFN- $\gamma$, but not IL-2, IL-4, or IL-9 (Grossman and Ratner, 1997). In contrast to primary tumor cells, tumor cell lines did not exhibit IL-1 expression, suggesting that IL-1 was expressed from a nonmalignant cell population infiltrating the LGL tumors. IL-1 can promote malignant cell growth and invasiveness, and also induce antitumor immunity (Apte and Voronov, 2002). High levels of GM-CSF in these transgenic mice may initiate neutrophilia, a characteristic finding for this animal model. IFN- $\gamma$ expression is likely a manifestation of the activated NK cell phenotype and may contribute to angiostatic regulation of these tumors. GzmB-Tax transgenic mice with homozygous deletion of IFN- $\gamma$ manifested earlier onset of tumors and enhanced angiogenesis, but no significant alteration in CD4 + or CD8 + immune responses (Mitra-Kaushik et al., 2004a).

The roles of other cytokines in this model remain to be determined. IL-6 is a pleiotropic cytokine, acting as an acute-phase reactant that regulates differentiation, proliferation, and survival of a wide variety of cell types (Horn et al., 2000). IL-10 suppresses inflammatory responses, and regulates the growth of $\mathrm{NK}$ and $\mathrm{T}$ cells, and other cell types (Scholz et al., 1996; Tsuruma et al., 1996; Furuya et al., 1999; Carvalho et al., 2001). Thus, IL-10 could play an immunoevasion role for HTLV-1 infection. The role of overexpressed ILs in HTLV-1 carcinogenesis remains unclear, but the future use of siRNAs and breeding with knockout mice should clarify their individual contributions. Inducible systems to test the requirement of Tax in tumor maintenance and allow differential expression of Tax in vivo are needed to verify the role of NF- $\kappa$ B in HTLV-1-mediated lymphoma. 
The p53 tumor suppressor and cell cycle regulatory protein is mutated in some HTLV-1-associated lymphomas, and is functionally inactivated by Tax when exogenously expressed in vitro (Mahieux et al., 2000; Pise-Masison et al., 2001; Gatza et al., 2003; Jeong et al., 2004). In p53 heterozygous mice, tumor onset was the same as p53 homozygous wild-type animals, but the heterozygous animals manifested more rapid tumor progression and death (Portis et al., 2001a). The molecular basis for this phenotype remains to be determined.

\section{Therapeutic modalities in HTLV-1 animal models}

Animal models of ATL have been quite useful in testing various anticancer therapeutic approaches. Based on the findings of NF- $\kappa$ B activation in ATL, several investigators have utilized these models to block NF- $\kappa \mathrm{B}$ expression. The proteasome inhibitor, borteozomib, inhibits the degradation of the inhibitor of NF- $\kappa \mathrm{B}$, $\mathrm{I} \kappa \mathrm{B} \alpha$. It was shown to inhibit NF- $\kappa \mathrm{B}$ activation in ATL cells and Tax transgenic tumor cells in culture and in mouse transplantation studies (Tan and Waldmann, 2002; Satou et al., 2004; Mitra-Kaushik et al., 2004b). In several of these studies, the majority of the cell death was found to be due to apoptosis. An inhibitor of NF- $\kappa$ B DNA-binding activity, Bay 11-7082, was also shown to block NF- $\kappa \mathrm{B}$ activity and resulted in tumor regression in ATL-transplanted NOD-SCID-gammac knockout mice (Dewan et al., 2003).

Treatment of ATL-bearing mice with a humanized anti-CD2 monoclonal antibody led to tumor regression (Zhang et al., 2003b). The activity of the mononclonal antibody was most likely due to antibody-dependent cellular cytotoxicity, since expression of $\mathrm{Fc} \gamma$ receptors on neutrophils and monocytes was required for activity. Treatment of ATL-bearing NOD-SCID mice with an $\alpha$-emitting radionuclide, bismuth 213 , conjugated to an antibody to the IL-2 receptor proved to be highly effective in inducing tumor regressions (Zhang et al., 2002). The activity of bismuth 213 in this model was greater than that of unconjugated antibody or radionuclide, or antibody conjugated to $\beta$-emitting radionuclide, yttrium 90. Flavopiridol, an inhibitor of cyclin-dependent kinases, was tested for its therapeutic efficacy alone and in combination with humanized antiTac antibody (HAT), which recognizes CD25, in a murine model of human ATL using MET-1 leukemic cells (Zhang et al., 2005). Either flavopiridol, given $2.5 \mathrm{mg} / \mathrm{kg}$ body weight daily for 5 days, or HAT, given $100 \mu \mathrm{g}$ weekly for 4 weeks, inhibited tumor growth and prolonged survival of the leukemia-bearing mice (Zhang et al., 2005). Collectively, these studies provide hope that ATL transplant and Tax transgenic models will provide new directions in the development of effective therapies against HTLV-1-induced lymphoproliferative diseases including ATL.

\section{Future prospects}

During the past 25 years since the first isolation of HTLV-1 from patients' cutaneous forms of ATL, a variety of animal models of HTLV-1 infection and transformation have expanded the understanding of the role of viral gene products and host factors that determine HTLV-1-mediated lymphocyte transformation. The knowledge gained from the study of animal models of HTLV-1 infection and disease can be extended to understand the pathogenesis and therapeutic intervention strategies of other tumors of hematopoietic origin. Future application of these animal models will also be critical in the development of vaccine approaches to elicit cellular immune responses to key viral proteins that mediated transformation, for example, Tax and to refine pharmacological targets to ablate HTLV-1-transformed T cells. Newer approaches using inducible expression systems (e.g. Cre lox recombinase) will need to be developed to address issues related to the role of viral gene products in the maintenance of the tumor phenotype in ATL. Moreover, recent studies of the HTLV-1 receptor suggest new approaches in using genetically engineered mouse models for HTLV-1 infection.

\section{Acknowledgements}

This work was supported by National Institute of Health grants RR-14324 and CA-100730 awarded to Dr Michael Lairmore and CA-70529 and CA-09338 awarded through the Ohio State University Comprehensive Cancer Center.

\section{References}

Akagi T, Takeda I, Oka T, Ohtsuki Y, Yano S and Miyoshi I. (1985). Jpn. J. Cancer Res., 76, 86-94.

Akari H, Suzuki T, Ikeda K, Hoshino H, Tomono T, Murotsuka T, Terao K, Ito H and Yoshikawa Y. (1997). Vaccine, 15, 1391-1395.

Albrecht B, Collins ND, Burniston MT, Nisbet JW, Ratner L, Green PL and Lairmore MD. (2000). J. Virol., 74, 9828-9835.

Albrecht B, D'Souza CD, Ding W, Tridandapani S, Coggeshall KM and Lairmore MD. (2002). J. Virol., 76, 3493-3501.

Apte RN and Voronov E. (2002). Semin. Cancer Biol., 12, 277-290.

Asquith B, Hanon E, Taylor GP and Bangham CR. (2000). Philos. Trans. R. Soc. Lond. Ser. B, 355, 1013-1019.

Bangham CR. (2000). J. Clin. Pathol., 53, 581-586.

Bangham CR. (2003a). Int. J. Hematol., 78, 297-303.

Bangham CR. (2003b). J. Gen. Virol., 84, 3177-3189.

Bartoe JT, Albrecht B, Collins ND, Robek MD, Ratner L, Green PL and Lairmore MD. (2000). J. Virol., 74, 1094-1100. 
Beilke MA, Traina-Dorge V, England JD and Blanchard JL. (1996). Arthritis Rheum., 39, 610-615.

Benvenisty N, Ornitz DM, Bennett GL, Sahagan BG, Kuo A, Cardiff RD and Leder P. (1992). Oncogene, 7, 2399-2405.

Berneman ZN, Gartenhaus RB, Reitz MS, Blattner WA, Manns A, Hanchard B, Ikehara O, Gallo RC and Klotman ME. (1992). Proc. Natl. Acad. Sci. USA, 89, 3005-3009.

Brauweiler A, Garrus JE, Reed JC and Nyborg JK. (1997). Virology, 231, 135-140.

Carvalho EM, Bacellar O, Porto AF, Braga S, Galvao-Castro B and Neva F. (2001). J. Acquir. Immune. Defic. Syndr., 27, $1-6$.

Cavrois M, Wainhobson S, Gessain A, Plumelle Y and Wattel E. (1996). Blood, 88, 4646-4650.

Chen Y, Lee T, Samuel K, Okayama A, Tachibana N, Miyoshi I, Papas T and Essex M. (1991). J. Immunol., 147, 2368-2376.

Ciminale V, D'Agostino D, Zotti L, Franchini G, Felber BK and Chieco-Bianchi L. (1995). Virology, 209, 445-456.

Ciminale V, Zotti L, Dagostino DM, Ferro T, Casareto L, Franchini G, Bernardi P and Chiecobianchi L. (1999). Oncogene, 18, 4505-4514.

Cleghorn FR, Manns A, Falk R, Hartge P, Hanchard B, Jack N, Williams E, Jaffe E, White F, Bartholomew C and Blattner W. (1995). J. Natl. Cancer Inst., 87, 1009-1014.

Cockerell GL, Lairmore MD, De B, Rovnak J, Hartley T and Miyoshi I. (1990). Int. J. Cancer, 45, 127-130.

Collins ND, Newbound GC, Albrecht B, Beard JL, Ratner L and Lairmore MD. (1998). Blood, 91, 4701-4707.

Collins ND, Newbound GC, Ratner L and Lairmore MD. (1996). J. Virol., 70, 7241-7246.

Conrad S, Byeon I, DiGeorge A, Lairmore M, Tsai M and Kaumaya P. (1995). Biomed. Pept. Prot. Nucleic Acids, 1, 83-92.

D'Agostino DM, Zotti L, Ferro T, Franchini G, ChiecoBianchi L and Ciminale V. (2000). AIDS Res. Hum. Retroviruses, 16, 1765-1770.

de La FC, Wang L, Wang D, Deng L, Wu K, Li H, Stein LD, Denny T, Coffman F, Kehn K, Baylor S, Maddukuri A, Pumfery A and Kashanchi F. (2003). Mol. Cell. Biochem., 245, 99-113.

Delebecque F, Pramberger K, Prevost MC, Brahic M and Tangy F. (2002). J. Virol., 76, 7883-7889.

Derse D, Mikovits J, Polianova M, Felber BK and Ruscetti F. (1995). J. Virol., 69, 1907-1912.

Dewan MZ, Terashima K, Taruishi M, Hasegawa H, Ito M, Tanaka Y, Mori N, Sata T, Koyanagi Y, Maeda M, Kubuki Y, Okayama A, Fujii M and Yamamoto N. (2003). J. Virol., 77, 5286-5294.

Ding W, Albrecht B, Kelley RE, Muthusamy N, Kim S, Altschuld RA and Lairmore MD. (2002). J. Virol., 76, 10374-10382.

Etoh K, Tamiya S, Yamaguchi K, Okayama A, Tsubouchi H, Ideta T, Mueller N, Takatsuki K and Matsuoka M. (1997). Cancer Res., 57, 4862-4867.

Fang JH, Kushida S, Feng RQ, Tanaka M, Kawamura T, Abe H, Maeda N, Onobori M, Hori M, Uchida K and Miwa M. (1998). J. Virol., 72, 3952-3957.

Felber BK, Paskalis H and Kleinmanewing C. (1985). Science, 229, 675-679.

Feng R, Kabayama A, Uchida K, Hoshino H and Miwa M. (2001). Jpn. J. Cancer Res., 92, 410-416.

Feng RQ, Tanaka H, Abe H, Arashi N, Sun BL, Uchida K and Miwa M. (1999). Jpn. J. Cancer Res., 90, 48-54.

Feuer G, Stewart SA, Baird SM, Lee F, Feuer R and Chen IS. (1995). J. Virol., 69, 1328-1333.
Feuer G, Zack JA, Harrington Jr WJ, Valderama R, Rosenblatt JD, Wachsman W, Baird SM and Chen IS. (1993). Blood, 82, 722-731.

Franchini G. (1995). Blood, 86, 3619-3639.

Franchini G, Nicot C and Johnson JM. (2003). Adv. Cancer Res., 89, 69-132.

Frangione-Beebe M, Albrecht B, Dakappagari N, Rose RT, Brooks CL, Schwendeman SP, Lairmore MD and Kaumaya PT. (2000). Vaccine, 19, 1068-1081.

Fujisawa K, Asahara H, Okamoto K, Aono H, Hasunuma T, Kobata T, Iwakura Y, Yonehara S, Sumida T and Nishioka K. (1996). J. Clin. Invest., 98, 271-278.

Furuta RA, Sugiura K, Kawakita S, Inada T, Ikehara S, Matsuda T and Fujisawa J. (2002a). J. Virol., 76, 2703-2713.

Furuta RA, Sugiura K, Kawakita S, Inada T, Ikehara S, Matsuda $\mathrm{T}$ and Fujisawa JJ. (2002b). J. Virol., 76, 2703-2713.

Furuya T, Nakamura T, Fujimoto T, Nakane S, Kambara C, Shirabe S, Hamasaki S, Motomura M and Eguchi K. (1999). J. Neuroimmunol., 95, 185-189.

Gabet AS, Gessain A and Wattel E. (2003). Int. J. Cancer, 107, 74-83.

Gatza ML, Watt JC and Marriott SJ. (2003). Oncogene, 22, 5141-5149.

Gessain A and Dethe G. (1996). Adv. Virus Res., 47, 377-426.

Grant C, Barmak K, Alefantis T, Yao J, Jacobson S and Wigdahl B. (2002). J. Cell. Physiol., 190, 133-159.

Grossman WJ and Ratner L. (1997). Blood, 90, 783-794.

Grossman WJ, Kimata JT, Wong FH, Zutter M, Ley TJ and Ratner L. (1995). Proc. Natl. Acad. Sci. USA, 92, 1057-1061.

Hakata Y, Yamada M and Shida H. (2001). J. Virol., 75, $11515-11525$

Hall AP, Irvine J, Blyth K, Cameron ER, Onions DE and Campbell ME. (1998). J. Pathol., 186, 209-214.

Hanabuchi S, Ohashi T, Koya Y, Kato H, Hasegawa A, Takemura F, Masuda T and Kannagi M. (2001). J. Natl. Cancer Inst., 93, 1775-1783.

Hasegawa A, Ohashi T, Hanabuchi S, Kato H, Takemura F, Masuda T and Kannagi M. (2003). J. Virol., 77, 2956-2963.

Hirose S, Kotani S, Uemura Y, Fujishita M, Taguchi H, Ohtsuki Y and Miyoshi I. (1988). Virology, 162, 487-489.

Hollsberg P, Wucherpfennig KW, Ausubel LJ, Calvo V, Bierer BE and Hafler DA. (1992). J. Immunol., 148, 3256-3263.

Homma T, Kanki PJ, King Jr NW, Hunt RD, O'Connell MJ, Letvin NL, Daniel MD, Desrosiers RC, Yang CS and Essex M. (1984). Science, 225, 716-718.

Horn F, Henze C and Heidrich K. (2000). Immunobiology, 202, $151-167$

Ibrahim F, Fiette L, Gessain A, Buisson N, Dethe G and Bomford R. (1994). Int. J. Cancer, 58, 446-451.

Ibuki K, Funahashi SI, Yamamoto H, Nakamura M, Igarashi T, Miura T, Ido E, Hayami M and Shida H. (1997). J. Gen. Virol., 78, 147-152.

Imada K, Takaorikondo A, Akagi T, Shimotohno K, Sugamura K, Hattori T, Yamabe H, Okuma $M$ and Uchiyama T. (1995). Blood, 86, 2350-2357.

Imada K, Takaorikondo A, Sawada H, Imura A, Kawamata S, Okuma M and Uchiyama T. (1996). Jpn. J. Cancer Res., 87, 887-892.

Ishiguro N, Abe M, Seto K, Sakurai H, Ikeda H, Wakisaka A, Togashi T, Tateno M and Yoshiki T. (1992). J. Exp. Med., 176, 981-989.

Ishihara S, Tachibana N, Okayama A, Murai K, Tsuda K and Mueller N. (1992). Jpn. J. Cancer Res., 83, 320-323. 
Iwahara Y, Takehara N, Kataoka R, Sawada T, Ohtsuki Y, Nakachi H, Maehama T, Okayama T and Miyoshi I. (1990). Int. J. Cancer, 45, 980-983.

Iwakura Y, Saijo S, Kioka Y, Nakayama-Yamada J, Itagaki K, Tosu M, Asano M, Kanai Y and Kakimoto K. (1995). J. Immunol., 155, 1588-1598.

Iwakura Y, Tosu M, Yoshida E, Takiguchi M, Sato K, Kitajima I, Nishioka K, Yamamoto K, Takeda T, Hatanaka M, Yamamoto H and Sekiguchi T. (1991). Science, 253, $1026-1028$

Iwanaga R, Ohtani K, Hayashi T and Nakamura M. (2001). Oncogene, 20, 2055-2067.

Jeang KT, Giam CZ, Majone F and Aboud M. (2004). J. Biol. Chem., 279, 31991-31994.

Jeang KT, Widen SG, Semmes OJ and Wilson SH. (1990). Science, 247, 1082-1083.

Jeong SJ, Radonovich M, Brady JN and Pise-Masison CA (2004). Blood, 104, 1490-1497.

Kanki PJ, Homma T, Lee TH, King Jr NW, Hunt RD and Essex M. (1985). Haematol. Blood Transfus., 29, 345-349.

Kannagi M, Ohashi T, Hanabuchi S, Kato H, Koya Y, Hasegawa A, Masuda T and Yoshiki T. (2000). AIDS Res. Hum. Retroviruses, 16, 1737-1740.

Kasai T, Ikeda H, Tomaru U, Yamashita I, Ohya O, Morita K, Wakisaka A, Matsuoka E, Moritoyo T, Hashimoto K, Higuchi I, Izumo S, Osame M and Yoshiki T. (1999). Acta Neuropathol., 97, 107-112.

Kataoka R, Takehara N, Iwahara Y, Sawada T, Ohtsuki Y, Dawei Y, Hoshino H and Miyoshi I. (1990). Blood, 76, $1657-1661$.

Kato H, Koya Y, Ohashi T, Hanabuchi S, Takemura F, Fujii M, Tsujimoto H, Hasegawa A and Kannagi M. (1998). J. Virol., 72, 7289-7293.

Kazanji M, Moreau JP, Mahieux R, Bonnemains B, Bomford R, Gessain A and Dethe G. (1997). Virology, 231, 258-266.

Kazanji M, Tartaglia J, Franchini G, de Thoisy B, Talarmin A, Contamin H, Gessain A and de The G. (2001). J. Virol., 75, 5939-5948.

Kazanji M. (2000). AIDS Res. Hum. Retroviruses, 16, 1741-1746.

Kazanji M, Ureta-Vidal A, Ozden S, Tangy F, de Thoisy B, Fiette L, Talarmin A, Gessain A and de The G. (2000). J. Virol., 74, 4860-4867.

Kehn K, Berro R, de La FC, Strouss K, Ghedin E, Dadgar S, Bottazzi ME, Pumfery A and Kashanchi F. (2004). Front. Biosci., 9, 2347-2372.

Kim SJ, Ding W, Albrecht B, Green PL and Lairmore MD. (2003). J. Biol. Chem., 278, 15550-15557.

Kimata JT, Wong F, Wang J and Ratner L. (1994). Virology, 204, 656-664

Kimzey AL and Dynan WS. (1999). J. Biol. Chem., 274, 34226-34232.

Kindt TJ, Said WA, Bowers FS, Mahana W, Zhao TM and Simpson RM. (2000). Microbes Infect., 2, 1139-1146.

Kiyokawa T, Seiki M, Iwashita S, Imagawa K, Shimizu F and Yoshida M. (1985). Proc. Natl. Acad. Sci. USA, 82, 8359-8363.

Kondo A, Imada $\mathrm{K}$, Hattori $\mathrm{T}$, Yamabe $\mathrm{H}$, Tanaka $\mathrm{T}$, Miyasaka M, Okuma M and Uchiyama T. (1993). Blood, 82, 2501-2509.

Kondo $\mathrm{T}$, Kono $\mathrm{H}$, Miyamoto $\mathrm{N}$, Yoshida $\mathrm{R}$, Toki $\mathrm{H}$, Matsumoto I, Hara M, Inoue $H$, Inatsuki $A$ and Funatsu $T$. (1989). Int. J. Cancer, 43, 1061-1064.

Koralnik IJ, Fullen J and Franchini G. (1993). J. Virol., 67, $2360-2366$
Koralnik IJ, Gessain A, Klotman ME, Lo MA, Berneman ZN and Franchini G. (1992). Proc. Natl. Acad. Sci. USA, 89, 8813-8817.

Kotani S, Yoshimoto S, Yamato K, Fujishita M, Yamashita M, Ohtsuki Y, Taguchi $\mathrm{H}$ and Miyoshi I. (1986). Int. J. Cancer, 37, 843-847.

Kushida S, Maeda N, Fang J, Uchida K and Miwa M. (1997). Leukemia, 11 (Suppl 3), 260-262.

Kushida S, Matsumura M, Tanaka H, Ami Y, Hori M, Kobayashi M, Uchida K, Yagami K, Kameyama T, Yoshizawa T, Mizusawa $\mathrm{H}$, Iwasaki $\mathrm{Y}$ and Miwa $\mathrm{M}$. (1993). Jpn. J. Cancer Res., 84, 831-833.

Lairmore MD, Roberts B, Frank D, Rovnak J, Weiser MG and Cockerell GL. (1992). Int. J. Cancer, 50, 124-130.

Lal R, Rudolph D, Palker T, Colligan J and Folks T. (1991). J. Gen. Virol., 72, 2321-2324.

Lenzmeier BA, Baird EE, Dervan PB and Nyborg JK. (1999). J. Mol. Biol., 291, 731-744.

Liu Y, Dole K, Stanley JR, Richard V, Rosol TJ, Ratner L, Lairmore M and Feuer G. (2002). Leukemia Res., 26, 561-567.

Mahieux R, Pise-Masison CA, Nicot C, Green P, Hall WW and Brady JN. (2000). AIDS Res. Hum. Retroviruses, 16, 1677-1681

McGinn TM, Tao B, Cartner S, Schoeb T, Davis I, Ratner L and Fultz PN. (2002). Virology, 304, 364-378.

Michael B, Nair AM, Hiraragi H, Shen L, Feuer G, BorisLawrie K and Lairmore MD. (2004). Retrovirology, 1, 39.

Mitra-Kaushik S, Harding J, Hess J, Schreiber R and Ratner L. (2004a). Blood, 104, 3305-3311.

Mitra-Kaushik S, Harding JC, Hess J and Ratner L. (2004b). Blood, 104, 802-809.

Miyoshi I, Takehara N, Sawada T, Iwahara Y, Kataoka R, Yang D and Hoshino H. (1992). Leukemia, 6 (Suppl 1), 24-26.

Miyoshi I, Yoshimoto S, Fujishita M, Kubonishi I, Taguchi H and Ohtsuki Y. (1984). Princess Takamatsu Symp., 15, 121-127.

Miyoshi I, Yoshimoto S, Kubonishi I, Fujishita M, Ohtsuki Y, Yamashita M, Yamato K, Hirose $\mathrm{S}$, Taguchi $\mathrm{H}$ and Niiya K. (1985). Int. J. Cancer, 35, 81-85.

Mortreux F, Gabet AS and Wattel E. (2003). Leukemia, 17, 26-38.

Mortreux F, Kazanji M, Gabet AS, de Thoisy B and Wattel E. (2001a). J. Virol., 75, 1083-1089.

Mortreux F, Leclercq I, Gabet AS, Leroy A, Westhof E, Gessain A, Wain-Hobson S and Wattel E. (2001b). J. Natl. Cancer Inst., 93, 367-377.

Murata N, Hakoda E, Machida H, Ikezoe T, Sawada T, Hoshino $\mathrm{H}$ and Miyoshi I. (1996). Leukemia, 10, 1971-1974.

Nakamura H, Hayami M, Ohta Y, Ishikawa K, Tsujimoto H, Kiyokawa T, Yoshida M, Sasagawa A and Honjo S. (1987). Int. J. Cancer, 40, 403-407.

Nakamura $\mathrm{H}$, Tanaka $\mathrm{Y}$, Tsujimoto AK, Ishikawa $\mathrm{K}$, Takadaya KI, Tozawa $\mathrm{H}$, Tsujimoto $\mathrm{H}$, Honjo $\mathrm{S}$ and Hayami M. (1986). Int. J. Cancer, 38, 867-875.

Nerenberg MI. (1990). Curr. Top. Microbiol. Immunol., 160, 121-128.

Nicot C, Dundr M, Johnson JM, Fullen JR, Alonzo N, Fukumoto R, Princler GL, Derse D, Misteli T and Franchini G. (2004). Nat. Med., 10, 197-201.

Nitta T, Tanaka M, Sun B, Hanai S and Miwa M. (2003). Biochem. Biophys. Res. Commun., 309, 161-165.

Nomura M, Ohashi T, Nishikawa K, Nishitsuji H, Kurihara K, Hasegawa A, Furuta RA, Fujisawa J, Tanaka Y, 
Hanabuchi S, Harashima N, Masuda T and Kannagi M. (2004). J. Virol., 78, 3827-3836.

Ogawa K, Matsuda S and Seto A. (1989). Leukemia Res., 13, 399-406.

Ohashi T, Hanabuchi S, Kato H, Koya Y, Takemura F, Hirokawa K, Yoshiki T, Tanaka Y, Fujii M and Kannagi M. (1999). J. Virol., 73, 6031-6040.

Ohsugi T, Ishibashi K, Shingu M and Nomura T. (1994). J. Vet. Med. Sci., 56, 601-603.

Ohsugi T, Yamaguchi K, Kumasaka T, Ishida T, Horie R, Watanabe T, Sakio N, Fujimoto T, Sakamoto N and Urano T. (2004). Lab. Invest., 84, 263-266.

Ohya O, Ikeda H, Tomaru U, Yamashita I, Kasai T, Morita $\mathrm{K}$, Wakisaka A and Yoshiki T. (2000). APMIS, 108, 459-466.

Ohya O, Tomaru U, Yamashita I, Kasai T, Morita K, Ikeda H, Wakisaka A and Yoshiki T. (1997). Leukemia, 11 (Suppl 3), 255-257.

Osame M, Janssen R, Kubota H, Nishitani H, Igata A, Nagataki S, Mori M, Goto I, Shimabukuro H, Khabbaz R and Kaplan J. (1990). Ann. Neurol., 28, 50-56.

Perini G, Wagner S and Green MR. (1995). Nature, 376, 602-605.

Pise-Masison CA, Mahieux R, Radonovich $\mathrm{M}$, Jiang $\mathrm{H}$ and Brady JN. (2001). J. Biol. Chem., 276, 200-205.

Portis T, Grossman WJ, Harding JC, Hess JL and Ratner L. (2001a). J. Virol., 75, 2185-2193.

Portis T, Harding JC and Ratner L. (2001b). Blood, 98, 1200-1208.

Ressler S, Morris GF and Marriott SJ. (1997). J. Virol., 71, 1181-1190.

Richard V, Lairmore MD, Green PL, Feuer G, Erbe RS, Albrecht B, D'Souza C, Keller ET, Dai J and Rosol TJ. (2001). Am. J. Pathol., 158, 2219-2228.

Robek MD, Wong FH and Ratner L. (1998). J. Virol., 72, 4458-4462.

Satou Y, Nosaka K, Koya Y, Yasunaga JI, Toyokuni S and Matsuoka M. (2004). Leukemia, 18, 1357-1363.

Sawada T, Iwahara Y, Ishii K, Taguchi H, Hoshino H and Miyoshi I. (1991). J. Infect. Dis., 164, 1193-1196.

Scholz C, Hafler DA and Hollsberg P. (1996). J. Neurosci. Res., 45, 786-794.

Seiki M, Hikikoshi A, Taniguchi T and Yoshida M. (1985). Science, 228, 1532-1534.

Seto A, Kawanishi M, Matsuda S, Ogawa K and Miyoshi I. (1988). Jpn. J. Cancer Res., 79, 335-341.

Silverman LR, Phipps AJ, Montgomery A, Ratner L and Lairmore MD. (2004). J. Virol., 78, 3837-3845.

Simpson RM, Leno M, Hubbard BS and Kindt TJ. (1996). J. Infect. Dis., 173, 722-726.

Sodroski J, Rosen C, Goh WC and Haseltine W. (1985). Science, 228, 1430-1434.

Stewart SA, Feuer G, Jewett A, Lee FV, Bonavida B and Chen ISY. (1996). Virology, 226, 167-175.

Suga T, Kameyama T, Shimotohno K, Matsumura M, Tanaka H, Kushida S, Ami Y, Uchida M, Uchida K and Miwa M. (1991). Int. J. Cancer, 49, 764-769.

Sun B, Fang J, Yagami K, Kushida S, Tanaka M, Uchida K and Miwa M. (1999). J. Neurol. Sci., 167, 16-21.

Sundaram R, Lynch MP, Rawale SV, Sun Y, Kazanji M and Kaumaya PT. (2004). J. Biol. Chem., 279, 24141-24151.

Taguchi H, Sawada T, Fukushima A, Iwata J, Ohtsuki Y, Ueno $\mathrm{H}$ and Miyoshi I. (1993). Lab. Invest., 69, 336-339.

Takehara N, Iwahara Y, Uemura Y, Sawada T, Ohtsuki Y, Iwai H, Hoshino H and Miyoshi I. (1989). Int. J. Cancer, 44, 332-336.
Takemura T, Yamashita M, Shimada MK, Ohkura S, Shotake T, Ikeda M, Miura T and Hayami M. (2002). J. Virol., 76, $1642-1648$.

Tan C and Waldmann TA. (2002). Cancer Res., 62 , 1083-1086.

Tanaka M, Sun B, Fang J, Nitta T, Yoshida T, Kohtoh S, Kikukawa H, Hanai S, Uchida K and Miwa M. (2001). J. Virol., 75, 4420-4423.

Tanaka Y, Tanaka R, Terada E, Koyanagi Y, Miyanokurosaki N, Yamamoto N, Baba E, Nakamura M and Shida H. (1994). J. Virol., 68, 6323-6331.

Tanaka Y, Zeng L, Shiraki H, Shida H and Tozawa H. (1991) J. Immunol., 147, 354-360.

Tomaru U, Ikeda H, Jiang X, Ohya O and Yoshiki T. (2003). J. Neurovirol., 9, 530-538.

Trovato R, Mulloy JC, Johnson JM, Takemoto S, de Oliveira MP and Franchini G. (1999). J. Virol., 73, 6460-6467.

Tsukahara T, Kannagi M, Ohashi T, Kato H, Arai M, Nunez G, Iwanaga Y, Yamamoto N, Ohtani K, Nakamura M and Fujii M. (1999). J. Virol., 73, 7981-7987.

Tsuruma T, Yagihashi A, Torigoe T, Okada Y, Sato N, Kikuchi K and Hirata K. (1996). Artif. Organs, 20, 895-897.

Uchiyama T, Yodoi J, Sagawa K, Takatsuki K and Uchino H. (1977). Blood, 50, 481-492.

Uchiyama T. (1996). J. Clin. Immunol., 16, 305-314.

Uemura Y, Kotani S, Yoshimoto S, Fujishita M, Yamashita M, Ohtsuki Y, Taguchi H and Miyoshi I. (1987). Blood, 69, 1255-1258.

Uemura Y, Kotani S, Yoshimoto S, Fujishita M, Yano S, Ohtsuki Y and Miyoshi I. (1986). Jpn. J. Cancer Res., 77, 970-973.

Wattel E, Vartanian JP, Pannetier C and Wainhobson S. (1995). J. Virol., 69, 2863-2868.

Wilks R, Hanchard B, Morgan O, Williams E, Cranston B, Smith ML, Rodgersjohnson P and Manns A. (1996). Int. J. Cancer, 65, 272-273.

Willems L, Burny A, Collete D, Dangoisse O, Dequiedt F, Gatot JS, Kerkhofs P, Lefebvre L, Merezak C, Peremans T, Portetelle D, Twizere JC and Kettmann R. (2000). AIDS Res. Hum. Retroviruses, 16, 1787-1795.

Yamaguchi K and Takatsuki K. (1993). Clin. Haematol., 6, 899-915.

Yamamoto H, Sekiguchi T, Itagaki K, Saijo S and Iwakura Y. (1993). Arthritis Rheum., 36, 1612-1620.

Yamamoto N, Hayami M, Komuro A, Schneider J, Hunsmann G, Okada M and Hinuma Y. (1984). Med. Microbiol. Immunol. (Berlin), 173, 57-64.

Ye J, Silverman L, Lairmore MD and Green PL. (2003). Blood, 102, 3963-3969.

Yoshida M, Miyoshi I and Hinuma Y. (1982). Proc. Natl. Acad. Sci. USA, 79, 2031-2035.

Yoshida M, Seiki M, Yamaguchi K and Takatsuki K. (1984). Proc. Natl. Acad. Sci. USA, 81, 2534-2537.

Yoshida M. (2001). Annu. Rev. Immunol., 19, 475-496.

Yoshiki T, Ikeda H, Tomaru U, Ohya O, Kasai T, Yamashita I, Morita K, Yamazaki H, Ishizu A, Nakamaru Y, Kikuchi K, Tanaka S and Wakisaka A. (1997). Leukemia, 11 (Suppl 3), 245-246.

Yoshiki T. (1995). Intervirology, 38, 229-237.

Younis I, Khair L, Dundr M, Lairmore MD, Franchini G and Green PL. (2004). J. Virol., 78, 11077-11083.

Zhang M, Yao Z, Garmestani K, Axworthy DB, Zhang Z, Mallett RW, Theodore LJ, Goldman CK, Brechbiel MW, Carrasquillo JA and Waldmann TA. (2002). Blood, 100, 208-216. 
Zhang M, Zhang Z, Goldman CK, Janik J and Waldmann TA. (2005). Blood, 105, 1231-1236.

Zhang W, Nisbet JW, Albrecht B, Ding W, Kashanchi F, Bartoe JT and Lairmore MD. (2001). J. Virol., 75, 9885-9895.

Zhang W, Nisbet JW, Bartoe JT, Ding W and Lairmore MD. (2000). J. Virol., 74, 11270-11277.

Zhang Z, Zhang M, Goldman CK, Ravetch JV and Waldmann TA. (2003a). Cancer Res., 63, 6453-6457.
Zhang Z, Zhang M, Ravetch JV, Goldman C and Waldmann TA. (2003b). Blood, 102, 284-288.

Zhao TM, Bryant MA, Kindt TJ and Simpson RM. (2002). AIDS Res. Hum. Retroviruses, 18, 253-258.

Zhao TM, Robinson MA, Bowers FS and Kindt TJ. (1995). J. Virol., 69, 2024-2030.

Zhao TM, Robinson MA, Sawasdikosol S, Simpson RM and Kindt TJ. (1993). Virology, 195, 271-274. 